Susumu Saito $\cdot$ Aritoshi Iida $\cdot$ Akihiro Sekine

Yukie Miura • Tsutomu Sakamoto • Chie Ogawa

Saori Kawauchi · Shoko Higuchi • Yusuke Nakamura

\title{
Identification of 197 genetic variations in six human methyltransferase genes in the Japanese population
}

Received: May 17, 2001 / Accepted: June 18, 2001

\begin{abstract}
Methylation is an important event in the biotransformation pathway for many drugs and xenobiotic compounds. We screened DNA from 48 Japanese individuals for single-nucleotide polymorphisms (SNPs) in six methyltransferase (MT) genes (catechol-O-MT, COMT; guanidinoacetate $N$-MT, GAMT; histamine $N$-MT, HNMT; nicotinamide $N$-MT, NNMT; phosphatidylethanolamine $N$-MT, PEMT; and phenylethanolamine $N$-MT, PNMT) by direct sequencing of their entire genomic regions except for repetitive elements. This approach identified 190 SNPs and seven insertion/deletion polymorphisms among the six genes. Of the 190 SNPs, 33 were identified in the COMT gene, 6 in $G A M T, 41$ in $H N M T, 8$ in NNMT, 98 in PEMT, and 4 in $P N M T$. Nine were located in $5^{\prime}$ flanking regions, 156 in introns, 10 in exons, and 15 in $3^{\prime}$ flanking regions. These variants may contribute to a more precise understanding of possible correlations between genotypes and disease-susceptibility phenotypes or risk for side effects from drugs.
\end{abstract}

Key words Single-nucleotide polymorphism (SNP) * Catechol- $O$-methyltransferase gene $(C O M T)$ Guanidinoacetate $N$-methyltransferase gene $(G A M T)$. Histamine $N$-methyltransferase gene $(H N M T) \cdot$ Nicotinamide $N$-methyltransferase gene $(N N M T) \cdot$ Phosphatidylethanolamine $N$-methyltransferase gene $(P E M T)$ Phenylethanolamine $N$-methyltransferase gene (PNMT)

S. Saito $\cdot$ A. Iida $\cdot$ A. Sekine $\cdot$ Y. Miura $\cdot$ T. Sakamoto $\cdot$ C. Ogawa $\cdot$ S. Kawauchi $\cdot$ S. Higuchi $\cdot$ Y. Nakamura

Laboratory for Genotyping, SNP Research Center, Institute of

Physical and Chemical Research, Tokyo, Japan

Y. Nakamura $(\bowtie)$

Laboratory of Molecular Medicine, Human Genome Center,

Institute of Medical Science, The University of Tokyo, 4-6-1

Shirokanedai, Minato-ku, Tokyo 108-8639, Japan

Tel. +81-3-5449-5372; Fax +81-3-5449-5433

e-mail: yusuke@ims.u-tokyo.ac.jp

\section{Introduction}

Methylation is an important feature of the biotransformation pathway for many drugs and xenobiotic compounds (Weinshilboum 1989). The reaction involves transfer of the activated methyl group of S-adenosyl-L-methionine (AdoMet) to the substrates.

Among the enzymes involved in such reactions, called methyltransferases, catechol- $O$-methyltransferase (COMT; EC 2.1.1.6) catalyzes the transfer of a methyl group from $S$ adenosylmethionine to catecholamines, a class of molecules that includes the neurotransmitters dopamine, epinephrine, and norepinephrine (Kopin 1985). $O$-methylation drives one of the major pathways for degrading catecholamine transmitters (Zhu and Conney 1998). In addition to its role in the metabolism of endogenous substances, COMT is important for metabolizing catechol drugs such as L-DOPA (Lautala et al. 2001). COMT is found in two forms in tissues, a cytoplasmic soluble form (S-COMT) and a membrane-bound form (MB-COMT) located in the rough endoplasmic reticulum (Salminen et al. 1990; Bertocci et al. 1991; Lundström et al. 1991; Ulmanen et al. 1997). The soluble enzyme appears to be the predominant form of COMT in most tissues. However, in humans the membranebound enzyme predominates in the brain and adrenal medulla, and also in pheochromocytomas (Tenhunen et al. 1994; Eisenhofer et al. 1998). The MB-COMT transcript differs from the S-COMT transcript in that the former contains a longer $5^{\prime}$ untranslated region (UTR) and its translation-start site lies 50 codons upstream from that of S-COMT (Tenhunen et al. 1994).

Lotta et al. (1995) identified a $G$ to A polymorphism in the COMT gene at codon 158, which leads to substitution of methionine for valine. This polymorphism is associated with a three- to fourfold difference in enzymatic activity (Lachman et al. 1996); i.e., homozygosity for the A allele, COMT ${ }^{\mathrm{Met}}$, is associated with low enzyme activity and thermolability. Individuals who are homozygous for the normal (valine) allele display relatively high activity and heat stability of COMT; heterozygotes usually 
display intermediate levels of COMT activity and heat stability.

Guanidinoacetate methyltransferase (GAMT; EC2.1.1.2) catalyzes the last step of creatine biosynthesis in mammals. Creatine is an important metabolite for cellular energy metabolism in a variety of tissues, e.g., skeletal, cardiac and smooth muscle, and brain (Walker 1979; Wallimann and Hemmer 1994). GAMT deficiency causes an inborn error in creatine biosynthesis (Stöckler et al. 1994, 1996a, 1996b, 1997; Carducci et al. 2000; Ilas et al. 2000). Deficiency of GAMT readily explains the accumulation of guanidinoacetate and the depletion of the total creatine pool in affected individuals.

Histamine $N$-methyltransferase (HNMT; EC 2.1.1.8) catalyzes a major metabolic pathway of histamine, a known neurotransmitter (Schwartz et al. 1991). Histamine plays an important role in allergic responses and is involved in regulating secretion of gastric acid (Wasserman 1983; Loiselle and Wollin 1993). Biochemical genetic studies of HNMT in human red blood cells demonstrated fivefold individual differences in the level of this enzyme's activity, mainly reflecting common genetic polymorphisms (Scott et al. 1988; Price et al. 1993). Preuss et al. (1998) demonstrated a C314T polymorphism in exon 4 in the $H N M T$ gene that resulted in a Thr105Ile amino acid substitution; they found that the T314 allele was associated with decreased levels of both HNMT enzymatic activity and immunoreactive protein. Therefore, the presence of a T314 allele would be expected to result in reduced histamine metabolism and increased bronchoconstriction. A number of investigators have examined potential associations of HNMT genotypes with altered susceptibilities to various diseases such as asthma (Yan et al. 2000a) and schizophrenia (Yan et al. 2000b).

Nicotinamide $N$-methyltransferase (NNMT; EC 2.1.1.1) catalyzes the $N$-methylation of nicotinamide and other pyridines to form pyridinium ions (Rini et al. 1989). Several diseases have been associated with abnormal nicotinamide metabolism that results in elevated levels of $N$ methylnicotinamide; these include idiopathic Parkinson's disease (Williams et al. 1993) and hepatic cirrhosis (Cuomo et al. 1994). NNMT enzymatic activity in human liver varies in a fivefold range, with a bimodal frequency distribution (Rini et al. 1989). Phenotypic differences in NNMT activity could reflect genetic polymorphisms; however, no sequence differences were seen when investigators compared cDNAs of individuals with high and low NNMT activity (Smith et al. 1998; Yan et al. 1999).

Phosphatidylethanolamine

$N$-methyltransferase (PEMT; EC2.1.1.17) converts phosphatidylethanolamine to phosphatidylcholine in mammalian liver (Vance et al. 1997). Immunolocalization experiments have detected two isoforms of PEMT, encoded by a single gene (Walkey et al. 1997). PEMT1, which constitutes the majority of PEMT activity, is located at the endoplasmic reticulum (Vance and Ridgway 1988), while PEMT2 is found on mitochondriaassociated membranes (Cui et al. 1993). The activity of PEMT is very low when hepatocytes are undifferentiated and proliferating rapidly. At birth, as hepatocyte proliferation slows and final differentiation begins, PEMT2 expres- sion increases dramatically. When hepatocyte proliferation was induced in adult rats by partial hepatectomy, PEMT2 expression was inhibited (Vance et al. 1997). Those results suggested that this enzyme might play a role in the regulation of hepatocyte growth and cell division (Walkey et al. 1999).

Phenylethanolamine $N$-methyltransferase (PNMT; EC 2.1.1.28) catalyzes the final step in the catecholamine biosynthetic pathway, converting norepinephrine to epinephrine (Axelrod and Weinshilboum 1972). It is primarily expressed in the adrenal medulla and the retina (Baetge et al. 1988). Its activity increases after stress in response to glucocorticoids and neuronal stimulation (Betito et al. 1994). Since defects in epinephrine metabolism have been implicated in the etiology of attention-deficit hyperactivity disorder (ADHD), aggression, and anxiety (Klinteberg and Magnusson 1989; Pliszka et al. 1994; Girardi et al. 1995; Hanna et al. 1996), PNMT is considered to be a candidate for a range of psychiatric disorders.

To investigate the nature of apparent genotype/phenotype correlations for methyltransferases more precisely, we began by searching for additional single-nucleotide polymorphisms (SNPs) in the six methyltransferase genes described above, including their promoter regions and introns but excluding repetitive elements. We report here a total of 197 genetic variations, of which 144 have not been reported before.

\section{Materials and methods}

Exon-intron boundaries of the COMT, GAMT, HNMT, $N N M T, P E M T$, and $P N M T$ genes were defined by comparing genomic sequences with mRNA sequences. Accession numbers of the genomic sequences obtained for this study are as follows:

COMT (AC000080.2), GAMT (NT_000879.1), HNMT (AC019304.3), NNMT (AC019290.3),

PEMT (AC020558.3), PNMT (AC040933.3)

Accession numbers of the mRNA sequences are as follows:

COMT (NM_000754.2, M65213.1),

GAMT (NM_000156.3), HNMT (NM_006895.1),

NNMT (U20970.1, U20971.1), PEMT (NM_007169.1,

AF113126.1, AF176807.1), PNMT (NM_002686.1)

Amplification of samples. Total genomic DNAs were isolated from peripheral leukocytes of 48 unrelated Japanese individuals by the standard phenol/chloroform extraction method. On the basis of sequence information from GenBank, we designed polymerase chain reaction (PCR) primers to amplify DNA fragments from all six genes, excluding repetitive elements, by invoking the Repeat Masker computer program in the manner described by Seki et al. (2000). We used $60 \mathrm{ng}$ of pooled DNA (20 ng from three individuals) for each PCR experiment. The reactions were performed as follows: initial denaturation at $94^{\circ} \mathrm{C}$ for $2 \mathrm{~min}$, 
followed by 35 cycles of amplification at $94^{\circ} \mathrm{C}$ for $30 \mathrm{~s}$, annealing at $60^{\circ} \mathrm{C}$ for $1 \mathrm{~min}$, and extension for $1 \mathrm{~min}$.

Direct sequencing and detection of polymorphisms. Products obtained from the PCR experiments were used as templates for direct sequencing and detection of SNPs, by the fluorescent dye-terminator cycle sequencing method (ABI PRISM Big Dye Terminator Cycle Sequencing Ready Reaction Kit; PerkinElmer, Foster City, CA, USA). These procedures were carried out according to methods we have described elsewhere (Ohnishi et al. 2000; Seki et al. 2000; Yamada et al. 2000).

\section{Results}

We screened 96 Japanese chromosomes for SNPs in six methyltransferase genes by direct DNA sequencing of a total of 103 kilobases of genomic DNA $(11 \mathrm{~kb}$ for the $C O M T$ gene, $5 \mathrm{~kb}$ for $G A M T, 27 \mathrm{~kb}$ for $H N M T, 5 \mathrm{~kb}$ for $N N M T, 52 \mathrm{~kb}$ for $P E M T$, and $3 \mathrm{~kb}$ for $P N M T)$. In these regions we identified a total of 190 SNPs and seven insertion/deletion polymorphisms among the six genes examined. On average, we identified one SNP in every 542 nucleotides.

Fig. $1(\mathrm{~A}-\mathrm{F})$ illustrates the location of each variation in the respective genes; detailed information about nucleotide positions and substitutions is summarized in Table 1 (A-F). Among the 190 SNPs listed there, 33 were identified in the COMT gene (average of one per $333 \mathrm{bp}$ ), 6 in GAMT (1/833bp), 41 in HNMT (1/659bp), 8 in NNMT (1/625bp), 98 in PEMT (1/531bp), and 4 in PNMT (1/750bp). Of the seven insertion/deletion polymorphisms, one was present in the COMT gene, four in HNMT, and two in PEMT.

Among the 33 SNPs found in the COMT gene, 5 were present in the $5^{\prime}$ flanking region, 21 in introns, 4 in exons, and 3 in the $3^{\prime}$ flanking region. Two of the exonic SNPs would cause substitution of amino acids (Ala72Ser in exon 3 and Val158Met in exon 4); both of these variants have been reported previously in the National Center for Biotechnology Information (NCBI) dbSNP database (rs6267 and rs165688, respectively). An insertion/deletion polymorphism was found in exon 6 (rs362204) corresponding to the $3^{\prime}$ untranslated region ( $3^{\prime}$ UTR). Of the 34 genetic variations we found in this gene, 17 were novel.

Of the six SNPs found in the GAMT gene, four were present in introns and two in the $3^{\prime}$ flanking region; none caused amino-acid substitutions. We were unable to find any SNPs in the $5^{\prime}$ flanking region or in the regions between exons 2 and 5.

As regards the HNMT gene, one of the 41 SNPs was present in the $5^{\prime}$ flanking region, 31 were in introns (20 of them in intron 5), 3 in exons, and 6 in the $3^{\prime}$ flanking region. Of the three exonic SNPs, the one at codon 105 in exon 4 would cause a substitution of isoleucine for threonine. This variant had been reported previously in the NCBI dbSNP database (rs1801105). Two known SNPs were identified in the 3' UTR in exon 6 (rs1050891 and rs1050900).
Table 1A. Summary of genetic variations detected in the COMT gene

\begin{tabular}{|c|c|c|c|c|}
\hline No. & Location & Position $^{a}$ & Genetic variation & NCBI SNP ID \\
\hline 1 & 5' Flanking & -1287 & $\mathrm{G} / \mathrm{A}$ & \\
\hline 2 & $5^{\prime}$ Flanking & -1217 & G/A & \\
\hline 3 & $5^{\prime}$ Flanking & -503 & $\mathrm{G} / \mathrm{A}$ & \\
\hline 4 & $5^{\prime}$ Flanking & -425 & $\mathrm{C} / \mathrm{T}$ & \\
\hline 5 & $5^{\prime}$ Flanking & -277 & $\mathrm{C} / \mathrm{T}$ & \\
\hline 6 & Intron 1 & 12058 & G/A & \\
\hline 7 & Intron 1 & 12070 & $\mathrm{~A} / \mathrm{G}$ & \\
\hline 8 & Intron 1 & 12074 & $\mathrm{G} / \mathrm{A}$ & rs1055503 \\
\hline 9 & Intron 1 & 17883 & $\mathrm{~T} / \mathrm{G}$ & rs174694 \\
\hline 10 & Intron 1 & 17963 & $\mathrm{~T} / \mathrm{C}$ & rs174695 \\
\hline 11 & Intron 1 & 18831 & $\mathrm{C} / \mathrm{T}$ & \\
\hline 12 & Intron 2 & 51 & $\mathrm{C} / \mathrm{G}$ & rs165656 \\
\hline 13 & Intron 2 & 201 & $\mathrm{C} / \mathrm{T}$ & rs165722 \\
\hline 14 & Intron 2 & 832 & $\mathrm{G} / \mathrm{C}$ & \\
\hline 15 & Intron 2 & 1140 & $\mathrm{~A} / \mathrm{G}$ & rs6269 \\
\hline 16 & Exon 3 & 186 & T/C(His62His) & rs4633 \\
\hline 17 & Exon 3 & 214 & G/T(Ala72Ser) & rs6267 \\
\hline 18 & Intron 3 & 90 & $\mathrm{~A} / \mathrm{G}$ & \\
\hline 19 & Intron 3 & 425 & $\mathrm{~T} / \mathrm{G}$ & \\
\hline 20 & Intron 3 & 671 & $\mathrm{G} / \mathrm{A}$ & \\
\hline 21 & Intron 3 & 676 & $\mathrm{G} / \mathrm{T}$ & \\
\hline 22 & Exon 4 & 119 & C/G(Leu136Leu) & rs 4818 \\
\hline 23 & Exon 4 & 183 & $\mathrm{G} / \mathrm{A}(\text { Val158Met })^{\mathrm{b}}$ & rs165688 \\
\hline 24 & Intron 5 & 75 & $\mathrm{G} / \mathrm{C}$ & \\
\hline 25 & Intron 5 & 310 & $\mathrm{C} / \mathrm{T}$ & \\
\hline 26 & Intron 5 & 346 & $\mathrm{G} / \mathrm{A}$ & \\
\hline 27 & Intron 5 & 679 & $\mathrm{C} / \mathrm{T}$ & rs165737 \\
\hline 28 & Intron 5 & 739 & $\mathrm{G} / \mathrm{A}$ & rs165774 \\
\hline 29 & Intron 5 & 2634 & $\mathrm{~T} / \mathrm{C}$ & rs174699 \\
\hline 30 & Intron 5 & 3023 & G/A & \\
\hline 31 & Exon 6 & 212 & C/del(3' UTR) & rs362204 \\
\hline 32 & 3' Flanking & 231 & $\mathrm{~A} / \mathrm{G}$ & rs165599 \\
\hline 33 & $3^{\prime}$ Flanking & 473 & $\mathrm{~T} / \mathrm{C}$ & rs165728 \\
\hline 34 & 3' Flanking & 1081 & $\mathrm{C} / \mathrm{A}$ & rs9265 \\
\hline
\end{tabular}

COMT, catechol- $O$-methyltransferase; NCBI, National Center for Biotechnology Information; SNP, single-nucleotide polymorphism; UTR, untranslated region

${ }^{a}$ For SNPs in the $5^{\prime}$ flanking, intron, or $3^{\prime}$ flanking regions, nucleotide positions are counted from the first intronic nucleotide at the exonintron junction; for SNPs in the exon region, from the first exonic nucleotide

${ }^{\mathrm{b}} \mathrm{SNP}$ previously reported by Lotta et al. (1995)

Table 1B. Summary of SNPs detected in the GAMT gene

\begin{tabular}{llcll}
\hline No. & Location & Position $^{\mathrm{a}}$ & SNP & NCBI SNP ID \\
\hline 1 & Intron 1 & 429 & $\mathrm{G} / \mathrm{A}$ & \\
2 & Intron 1 & 529 & $\mathrm{~T} / \mathrm{C}$ & rs266806 \\
3 & Intron 1 & 616 & $\mathrm{~T} / \mathrm{C}$ & rs266807 \\
4 & Intron 5 & 1411 & $\mathrm{G} / \mathrm{A}$ & \\
5 & 3' Flanking & 136 & $\mathrm{~A} / \mathrm{G}$ & rs266813 \\
6 & 3' Flanking & 626 & $\mathrm{G} / \mathrm{A}$ & rs740446 \\
\hline
\end{tabular}

GAMT, guanidinoacetate $N$-methyltransferase

Among the eight SNPs we found in the NNMT gene, one was in the $5^{\prime}$ flanking region, six were in introns, and one was in the $3^{\prime}$ flanking region.

In the PEMT gene, of the 98 SNPs found, 93 were intronic; 3 were in exons, and 2 were in the $3^{\prime}$ flanking region. Two of the exonic SNPs would cause amino acid substitutions (Val58Leu in exon 5 and Ala175Thr in exon 


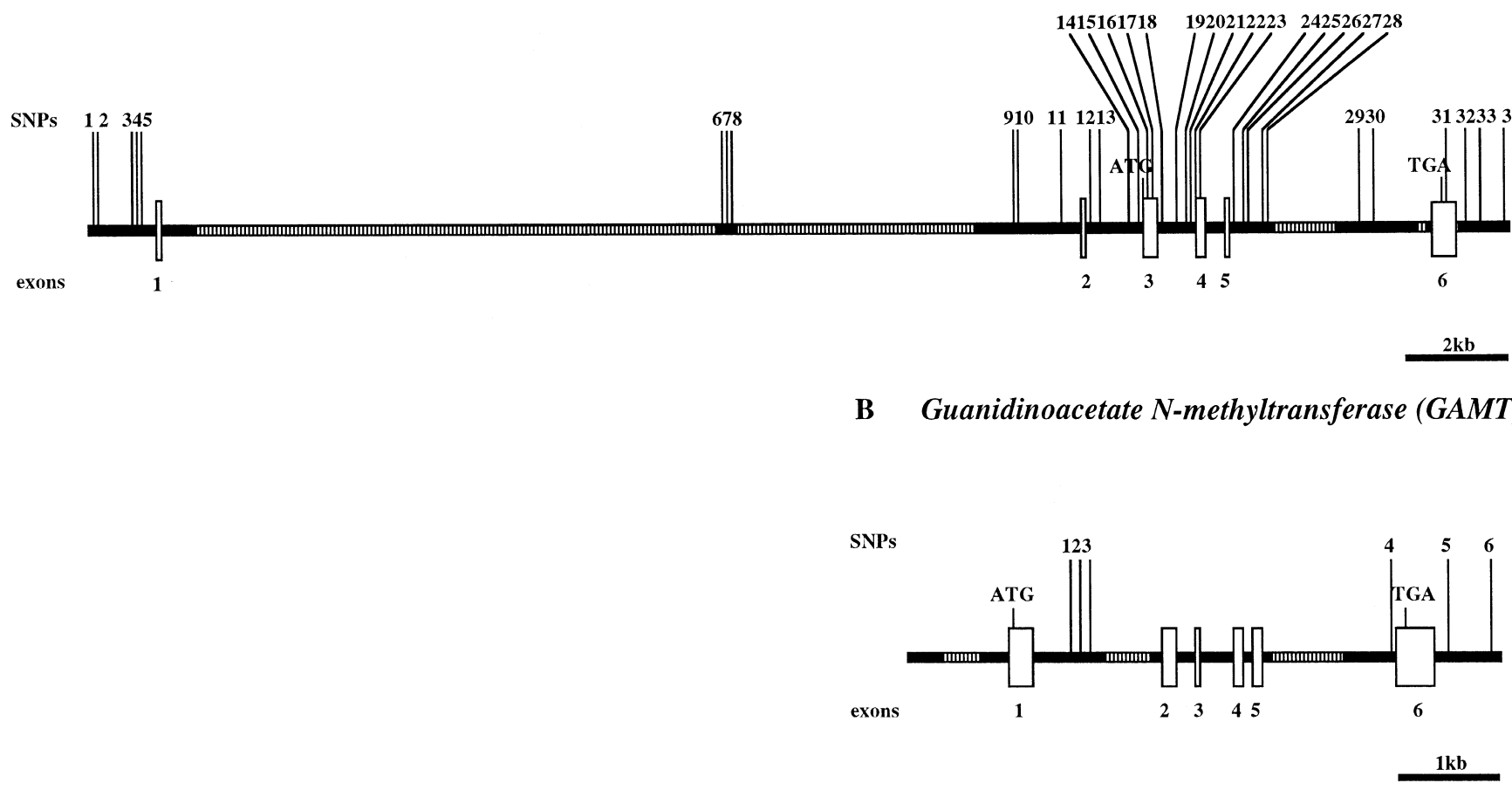

C Histamine N-methyltransferase (HNMT)
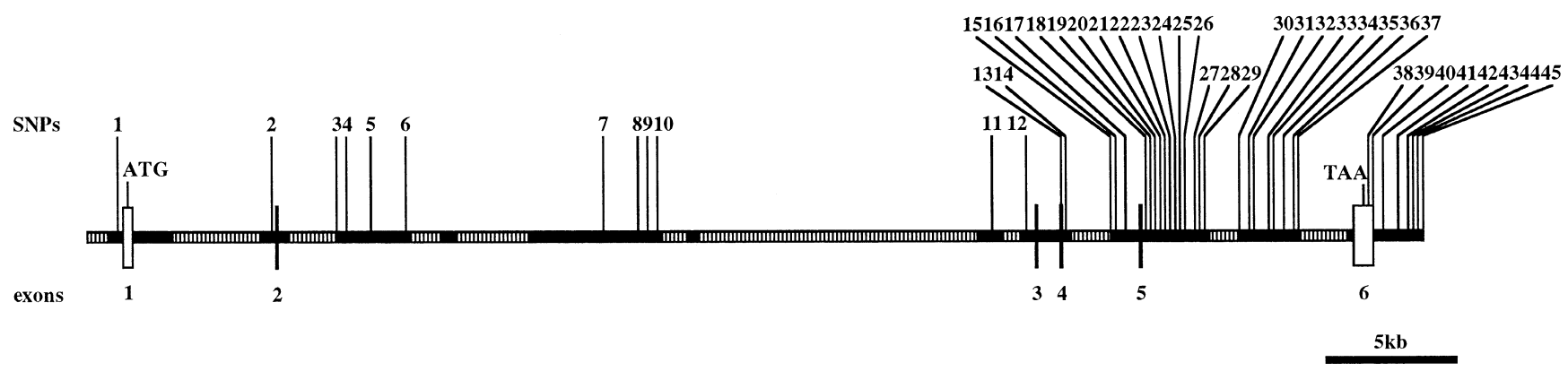

D Nicotinamide N-methyltransferase (NNMT)

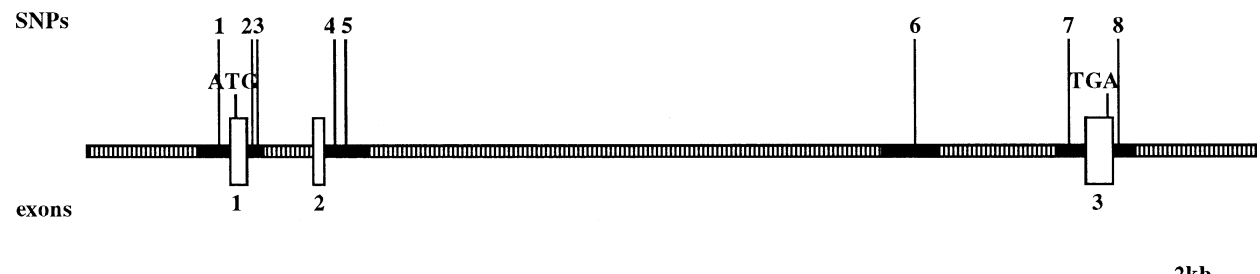

Fig. 1. Locations of single-nucleotide polymorphisms ( $S N P S)$ in the COMT (A), GAMT (B), HNMT (C), NNMT (D), PEMT (E), and PNMT (F) genes, indicated by vertical lines. Open boxes represent exons; hatching on the chromosomes indicates regions of repetitive elements; $(A T G)$ and $(T G A$ or $T A A)$, initiation and stop codons, respectively 


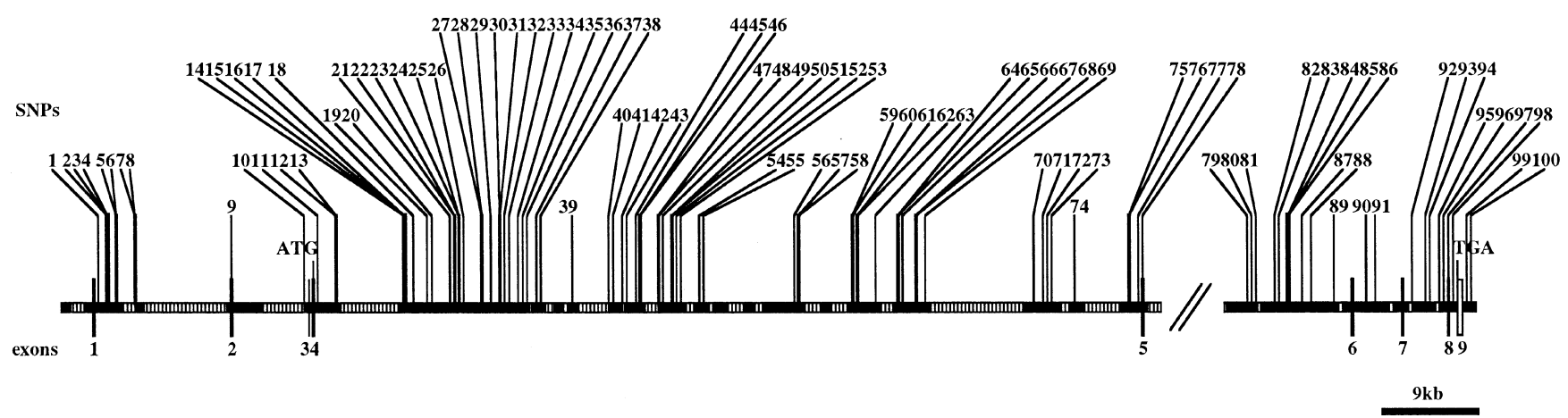

F Phenylethanolamine N-methyltransferase (PNMT)

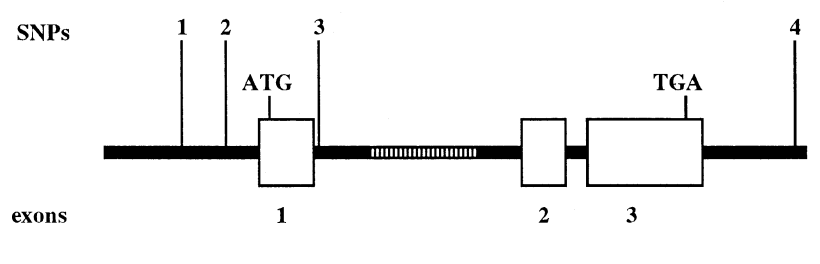

Fig. 1. Continued

8). Both of those variants have been reported in the NCBI dbSNP database (rs897453 and rs1918248, respectively).

Among the four SNPs detected in the PNMT gene, two were located in the $5^{\prime}$ flanking region, one in an intron, and one in the $3^{\prime}$ flanking region. Both SNPs in the 5' flanking region were reported previously (Wu and Comings 1999).

\section{Discussion}

We identified 197 genetic variations (190 SNPs and 7 insertion/deletion polymorphisms) by screening the entire genomic regions, except for repetitive sequences, encoding six methyltransferase genes (COMT, GAMT, HNMT, NNMT, $P E M T$, and $P N M T$ ) in the Japanese population. Of the 197 genetic variations detected, 144 (73\%) have not been reported before (17 in the COMT gene, 2 in $G A M T, 32$ in $H N M T, 6$ in NNMT, 86 in PEMT, and 1 in PNMT).

When we investigated SNPs in these six genes using the NCBI dbSNP database, we noticed that 18 exonic SNPs in the archive were absent from our 96-chromosome Japanese population sample. Of those "missing" SNPs, eight had been reported in the COMT gene: rs1805052 (5' UTR) in exon 1; rs6270 (Cys34Ser) and rs740602 (Gln73Gln) in exon 3; rs769223 (Ala134Ala) in exon 4; rs769224 (Pro199Pro) and rs165631 (Leu203Leu) in exon 5; and rs12814 (3' UTR) and rs14968 (3' UTR) in exon 6. Three were in the GAMT gene: rs1050914 (Val165Phe; exon5) and rs659455 and rs659460 in the 3' UTR of exon 6. The archive also showed one [rs1050207 (Thr245Pro)] in exon 3 of the NNMT gene and six in exon 3 of the PNMT gene [rs5638 (Lys152Llys), rs5639 (Ser188Cys), rs5640 (Leu211His), rs5641 (Leu217Gln), rs5642 (Arg254His), and rs5643 (Trp276Arg)]. Since Yan et al. (1999) detected no SNPs or insertion/deletion events within either exons or 5' flanking regions of NNMT and Smith et al. (1998) reported the same result, the archived SNPs may be very rare substitutions or limited to some ethnic group, or they may reflect sequencing errors.

In the COMT gene, we identified two SNPs that caused amino acid substitutions, Ala72Ser in exon 3 and Val158Met in exon 4. Lachman et al. (1996) demonstrated that the Val158Met polymorphism in exon 4 was associated with a three- to fourfold difference in the enzyme's activity; however, it is unclear whether the Ala72Ser polymorphism in exon 3 would alter enzymatic activity. Transcription of the COMT gene is controlled by two distinct promoter regions (Tenhunen et al. 1994); the proximal promoter (P1), located between the S- and MB-COMT ATG start codons, regulates expression of S-COMT mRNA; MB-COMT transcription is controlled by the distal promoter $(\mathrm{P} 2)$. We 
Table 1C. Summary of genetic variations detected in the HNMT gene

\begin{tabular}{|c|c|c|c|c|}
\hline No. & Location & Position $^{a}$ & Genetic variation & NCBI SNP ID \\
\hline 1 & $5^{\prime}$ Flanking & -211 & $\mathrm{C} / \mathrm{T}$ & \\
\hline 2 & Intron 1 & 5409 & $\mathrm{~A} / \mathrm{G}$ & \\
\hline 3 & Intron 2 & 2561 & $\mathrm{~A} / \mathrm{G}$ & \\
\hline 4 & Intron 2 & 2895 & $\mathrm{~A} / \mathrm{C}$ & \\
\hline 5 & Intron 2 & 3977 & $\mathrm{G} / \mathrm{A}$ & \\
\hline 6 & Intron 2 & 5296 & $\mathrm{~T} / \mathrm{C}$ & \\
\hline 7 & Intron 2 & 13317 & $\mathrm{C} / \mathrm{T}$ & \\
\hline 8 & Intron 2 & 14682 & A/del & \\
\hline 9 & Intron 2 & 15047 & $\mathrm{C} / \mathrm{T}$ & rs1020678 \\
\hline 10 & Intron 2 & 15406 & $\mathrm{G} / \mathrm{A}$ & \\
\hline 11 & Intron 2 & 28943 & $\mathrm{~A} / \mathrm{G}$ & \\
\hline 12 & Intron 2 & 30390 & $\mathrm{~T} / \mathrm{A}$ & rs973013 \\
\hline 13 & Exon 4 & 16 & $\mathrm{C} / \mathrm{T}(\mathrm{Thr} 105 \mathrm{Ile})^{\mathrm{c}}$ & rs1801105 \\
\hline 14 & Intron 4 & 49 & $\mathrm{~A} / \mathrm{G}$ & \\
\hline 15 & Intron 4 & 1404 & $\mathrm{G} / \mathrm{T}$ & rs1455167 \\
\hline 16 & Intron 4 & $1942-1943$ & $\mathrm{~A} / \mathrm{ins}$ & \\
\hline 17 & Intron 4 & 2405 & $\mathrm{C} / \mathrm{A}$ & \\
\hline 18 & Intron 5 & 80-81 & TT/ins & \\
\hline 19 & Intron 5 & 235 & $\mathrm{~T} / \mathrm{C}$ & \\
\hline 20 & Intron 5 & $702-703$ & AT/ins & \\
\hline 21 & Intron 5 & 749 & $\mathrm{~T} / \mathrm{G}$ & \\
\hline 22 & Intron 5 & 1101 & $\mathrm{~T} / \mathrm{G}$ & \\
\hline 23 & Intron 5 & 1137 & G/A & \\
\hline 24 & Intron 5 & 1348 & $\mathrm{C} / \mathrm{G}$ & \\
\hline 25 & Intron 5 & 1517 & $\mathrm{~A} / \mathrm{G}$ & rs1378321 \\
\hline 26 & Intron 5 & 1673 & $\mathrm{C} / \mathrm{G}$ & \\
\hline 27 & Intron 5 & 2022 & $\mathrm{C} / \mathrm{T}$ & \\
\hline 28 & Intron 5 & 2253 & $\mathrm{~A} / \mathrm{G}$ & rs1455162 \\
\hline 29 & Intron 5 & 2285 & $\mathrm{G} / \mathrm{C}$ & \\
\hline 30 & Intron 5 & 4159 & $\mathrm{C} / \mathrm{T}$ & \\
\hline 31 & Intron 5 & 4501 & $\mathrm{C} / \mathrm{G}$ & \\
\hline 32 & Intron 5 & 4729 & $\mathrm{G} / \mathrm{T}$ & rs993891 \\
\hline 33 & Intron 5 & 5251 & $\mathrm{C} / \mathrm{G}$ & \\
\hline 34 & Intron 5 & 5296 & $\mathrm{~A} / \mathrm{C}$ & rs1455159 \\
\hline 35 & Intron 5 & 5802 & $\mathrm{C} / \mathrm{T}$ & \\
\hline 36 & Intron 5 & 6189 & $\mathrm{G} / \mathrm{C}$ & \\
\hline 37 & Intron 5 & 6297 & $\mathrm{~T} / \mathrm{A}$ & \\
\hline 38 & Exon 6 & 416 & A/G(3' UTR) & rs1050891 \\
\hline 39 & Exon 6 & 574 & A/T(3' UTR) & rs1050900 \\
\hline 40 & $3^{\prime}$ Flanking & 458 & $\mathrm{C} / \mathrm{T}$ & \\
\hline 41 & 3' Flanking & 993 & $\mathrm{G} / \mathrm{A}$ & \\
\hline 42 & 3' Flanking & 1402 & $\mathrm{C} / \mathrm{T}$ & rs1455158 \\
\hline 43 & 3' Flanking & 1516 & $\mathrm{~T} / \mathrm{C}$ & rs1455157 \\
\hline 44 & 3' Flanking & 1575 & $\mathrm{C} / \mathrm{G}$ & rs1455156 \\
\hline 45 & $3^{\prime}$ Flanking & 1793 & G/A & \\
\hline
\end{tabular}

HNMT, histamine $N$-methyltransferase; del, deletion; ins, insertion ${ }^{\mathrm{c}} \mathrm{SNP}$ previously reported by Preuss et al. (1998)

Table 1D. Summary of SNPs detected in the NNMT gene

\begin{tabular}{llrll}
\hline No. & Location & Position $^{\mathrm{a}}$ & SNP & NCBI SNP ID \\
\hline 1 & 5' Flanking & -228 & $\mathrm{~A} / \mathrm{T}$ & \\
2 & Intron 1 & 44 & $\mathrm{~T} / \mathrm{C}$ & \\
3 & Intron 1 & 149 & $\mathrm{~A} / \mathrm{G}$ & \\
4 & Intron 2 & 158 & $\mathrm{G} / \mathrm{A}$ & $\mathrm{rs} 1941404$ \\
5 & Intron 2 & 433 & $\mathrm{~T} / \mathrm{C}$ & $\mathrm{rs} 1894030$ \\
6 & Intron 2 & 10826 & $\mathrm{C} / \mathrm{T}$ & \\
7 & Intron 2 & 13630 & $\mathrm{~T} / \mathrm{C}$ & \\
8 & 3' Flanking & 71 & $\mathrm{~A} / \mathrm{G}$ & \\
\hline
\end{tabular}

NNMT, nicotinamide $N$-methyltransferase found five SNPs in the region corresponding to the P2 promoter, and one (intron $2+1140$, rs6269) in the P1 promoter region. These SNPs may have some effect on transcription of the MB-COMT and S-COMT mRNAs. Since COMT is a major conjugation enzyme for the catechol iatrogenes and its genetic polymorphism is thought to correlate with its enzymic activity, a number of investigators have examined potential associations of COMT genotypes with altered susceptibilities to various diseases, for example breast cancer (Lavigne et al. 1997; Millikan et al. 1998; Thompson et al. 1998; Huang et al. 1999) and ovarian cancer (Goodman et al. 2000). Some of these investigators have reported an association of the COMT genotype with risk for breast cancer, but others have found no relation between genotype and risk of either breast or ovarian cancer. The novel SNPs in $C O M T$ published here should contribute to further explorations of potential relationships between COMT allelic status and susceptibility to certain diseases.

In the $G A M T$ gene, we found no SNP that would cause an amino acid substitution. Although mutations causing severe GAMT deficiency have been reported (Stöckler et al. 1994, 1996a, 1996b, 1997; Carducci et al. 2000; Ilas et al. 2000), no SNPs that may correlate with diseasesusceptibility phenotypes have been reported to date.

In the HNMT gene, one SNP we detected in exon 4 would substitute an amino acid, Thr105Ile. This polymorphism, which was reported previously (Preuss et al. 1998), has been associated with altered HNMT activity. In fact, potential associations between $H N M T$ genotypes and susceptibility to asthma (Yan et al. 2000a) and schizophrenia (Yan et al. 2000b), have been investigated, but without conclusive results. Hence, the novel SNPs reported here may serve as additional tools for further exploration of possible relationships between an individual's $H N M T$ genotype and susceptibility to certain diseases.

As regards the NNMT gene, we found no SNP causing an amino acid substitution, as previous reports have indicated as well (Smith et al. 1998; Yan et al. 1999). However, we detected one SNP in the $5^{\prime}$ flanking region that might be capable of influencing transcriptional efficiency.

In the PEMT gene, we found two SNPs that would substitute amino acids, Val58Leu in exon 5 and Ala175Thr in exon 8 , but it is unclear whether these changes would alter the enzyme's activity. However, the eight SNPs and two insertion/deletion polymorphisms we identified in intron 1 , exon 2 , and intron 2 might influence transcriptional efficiency.

Although we found no SNP in the PNMT gene that would cause amino acid substitution, we did identify two in the 5' flanking region. Since PNMT may be an important component of the mammalian stress response and is considered to be a candidate for a wide range of psychiatric disorders, the two SNPs in the putative promoter region may be useful for investigating a possible role of this gene in mental illnesses. 
Table 1E. Summary of genetic variations detected in the PEMT gene

\begin{tabular}{|c|c|c|c|c|c|c|c|c|c|}
\hline No. & Location & Position $^{\mathrm{a}}$ & Genetic variation & NCBI SNP ID & No. & Location & Position $^{\mathrm{a}}$ & Genetic variation & NCBI SNP ID \\
\hline 1 & Intron 1 & 297-299 & TGT/del & & 51 & Intron 4 & 23627 & $\mathrm{C} / \mathrm{T}$ & \\
\hline 2 & Intron 1 & 817 & $\mathrm{~A} / \mathrm{G}$ & & 52 & Intron 4 & 23941 & $\mathrm{G} / \mathrm{A}$ & \\
\hline 3 & Intron 1 & 830 & $\mathrm{G} / \mathrm{A}$ & & 53 & Intron 4 & 24091 & $\mathrm{G} / \mathrm{T}$ & \\
\hline 4 & Intron 1 & 1035 & $\mathrm{~T} / \mathrm{C}$ & & 54 & Intron 4 & 25348 & $\mathrm{G} / \mathrm{A}$ & \\
\hline 5 & Intron 1 & 1573 & $\mathrm{C} / \mathrm{T}$ & & 55 & Intron 4 & 25603 & $\mathrm{G} / \mathrm{A}$ & \\
\hline 6 & Intron 1 & 1759 & $\mathrm{~A} / \mathrm{G}$ & & 56 & Intron 4 & 31540 & $\mathrm{~T} / \mathrm{C}$ & \\
\hline 7 & Intron 1 & 2768 & $\mathrm{C} / \mathrm{A}$ & & 57 & Intron 4 & 31637 & $\mathrm{G} / \mathrm{A}$ & \\
\hline 8 & Intron 1 & 2785 & $\mathrm{~T} / \mathrm{C}$ & & 58 & Intron 4 & 31642 & $\mathrm{G} / \mathrm{A}$ & \\
\hline 9 & Exon 2 & 162 & $\mathrm{C} / \mathrm{T}\left(5^{\prime} \mathrm{UTR}\right)$ & & 59 & Intron 4 & 35593 & $\mathrm{G} / \mathrm{A}$ & \\
\hline 10 & Intron 2 & 4598 & $\mathrm{~T} / \mathrm{del}$ & & 60 & Intron 4 & 35647 & $\mathrm{C} / \mathrm{A}$ & \\
\hline 11 & Intron 4 & 39 & $\mathrm{C} / \mathrm{T}$ & & 61 & Intron 4 & 35862 & $\mathrm{C} / \mathrm{T}$ & \\
\hline 12 & Intron 4 & 1317 & $\mathrm{G} / \mathrm{A}$ & & 62 & Intron 4 & 35882 & $\mathrm{~T} / \mathrm{G}$ & \\
\hline 13 & Intron 4 & 1355 & $\mathrm{~A} / \mathrm{C}$ & & 63 & Intron 4 & 37141 & $\mathrm{~T} / \mathrm{C}$ & \\
\hline 14 & Intron 4 & 5925 & $\mathrm{C} / \mathrm{T}$ & & 64 & Intron 4 & 38862 & $\mathrm{C} / \mathrm{G}$ & \\
\hline 15 & Intron 4 & 6028 & $\mathrm{G} / \mathrm{C}$ & & 65 & Intron 4 & 38872 & $\mathrm{G} / \mathrm{T}$ & \\
\hline 16 & Intron 4 & 6078 & $\mathrm{C} / \mathrm{T}$ & & 66 & Intron 4 & 39140 & $\mathrm{C} / \mathrm{T}$ & \\
\hline 17 & Intron 4 & 6089 & $\mathrm{~A} / \mathrm{G}$ & & 67 & Intron 4 & 39635 & $\mathrm{G} / \mathrm{T}$ & \\
\hline 18 & Intron 4 & 6379 & G/A & & 68 & Intron 4 & 39713 & $\mathrm{C} / \mathrm{T}$ & \\
\hline 19 & Intron 4 & 7339 & $\mathrm{C} / \mathrm{T}$ & & 69 & Intron 4 & 40436 & $\mathrm{G} / \mathrm{A}$ & rs936108 \\
\hline 20 & Intron 4 & 7619 & $\mathrm{~A} / \mathrm{G}$ & & 70 & Intron 4 & 47485 & $\mathrm{C} / \mathrm{T}$ & \\
\hline 21 & Intron 4 & 8858 & $\mathrm{~T} / \mathrm{G}$ & & 71 & Intron 4 & 48131 & $\mathrm{G} / \mathrm{A}$ & \\
\hline 22 & Intron 4 & 9029 & $\mathrm{G} / \mathrm{A}$ & & 72 & Intron 4 & 48558 & $\mathrm{C} / \mathrm{G}$ & \\
\hline 23 & Intron 4 & 9056 & $\mathrm{C} / \mathrm{T}$ & & 73 & Intron 4 & 48702 & G/A & \\
\hline 24 & Intron 4 & 9512 & $\mathrm{~A} / \mathrm{G}$ & & 74 & Intron 4 & 50302 & $\mathrm{~T} / \mathrm{C}$ & \\
\hline 25 & Intron 4 & 9523 & $\mathrm{~T} / \mathrm{C}$ & & 75 & Intron 4 & 54102 & $\mathrm{~A} / \mathrm{T}$ & rs746900 \\
\hline 26 & Intron 4 & 9622 & G/A & & 76 & Intron 4 & 54220 & $\mathrm{G} / \mathrm{A}$ & rs746899 \\
\hline 27 & Intron 4 & 10776 & $\mathrm{G} / \mathrm{A}$ & & 77 & Intron 4 & 54371 & $\mathrm{G} / \mathrm{A}$ & \\
\hline 28 & Intron 4 & 10912 & $\mathrm{G} / \mathrm{C}$ & & 78 & Exon 5 & 79 & G/C(Val58Leu $)$ & rs897453 \\
\hline 29 & Intron 4 & 11590 & $\mathrm{G} / \mathrm{C}$ & & 79 & Intron 5 & -6796 & $\mathrm{~A} / \mathrm{C}$ & rs748196 \\
\hline 30 & Intron 4 & 12090 & $\mathrm{G} / \mathrm{C}$ & & 80 & Intron 5 & -6636 & $\mathrm{~T} / \mathrm{C}$ & rs897456 \\
\hline 31 & Intron 4 & 12263 & $\mathrm{G} / \mathrm{A}$ & & 81 & Intron 5 & -6448 & $\mathrm{G} / \mathrm{A}$ & \\
\hline 32 & Intron 4 & 12448 & $\mathrm{G} / \mathrm{A}$ & & 82 & Intron 5 & -5218 & $\mathrm{C} / \mathrm{G}$ & \\
\hline 33 & Intron 4 & 12730 & $\mathrm{C} / \mathrm{T}$ & rs744925 & 83 & Intron 5 & -4824 & $\mathrm{G} / \mathrm{A}$ & \\
\hline 34 & Intron 4 & 13240 & $\mathrm{~T} / \mathrm{C}$ & rs897451 & 84 & Intron 5 & -4249 & $\mathrm{C} / \mathrm{A}$ & \\
\hline 35 & Intron 4 & 13494 & $\mathrm{~T} / \mathrm{C}$ & & 85 & Intron 5 & -4230 & $\mathrm{C} / \mathrm{T}$ & \\
\hline 36 & Intron 4 & 13817 & $\mathrm{~A} / \mathrm{G}$ & & 86 & Intron 5 & -4182 & $\mathrm{G} / \mathrm{A}$ & \\
\hline 37 & Intron 4 & 14773 & $\mathrm{C} / \mathrm{T}$ & & 87 & Intron 5 & -3369 & $\mathrm{G} / \mathrm{C}$ & \\
\hline 38 & Intron 4 & 14951 & G/A & rs1531098 & 88 & Intron 5 & -2625 & $\mathrm{C} / \mathrm{T}$ & \\
\hline 39 & Intron 4 & 16896 & $\mathrm{~T} / \mathrm{C}$ & & 89 & Intron 5 & -1200 & $\mathrm{~A} / \mathrm{T}$ & \\
\hline 40 & Intron 4 & 19439 & $\mathrm{G} / \mathrm{A}$ & & 90 & Intron 6 & 606 & $\mathrm{~A} / \mathrm{G}$ & \\
\hline 41 & Intron 4 & 19557 & $\mathrm{C} / \mathrm{T}$ & & 91 & Intron 6 & 1229 & $\mathrm{G} / \mathrm{A}$ & rs 1242390 \\
\hline 42 & Intron 4 & 20051 & $\mathrm{~A} / \mathrm{G}$ & & 92 & Intron 7 & 716 & $\mathrm{C} / \mathrm{G}$ & \\
\hline 43 & Intron 4 & 20816 & $\mathrm{C} / \mathrm{T}$ & & 93 & Intron 7 & 1537 & $\mathrm{G} / \mathrm{A}$ & \\
\hline 44 & Intron 4 & 21196 & $\mathrm{C} / \mathrm{G}$ & & 94 & Intron 7 & 1718 & $\mathrm{~T} / \mathrm{C}$ & rs1020697 \\
\hline 45 & Intron 4 & 21528 & $\mathrm{G} / \mathrm{T}$ & & 95 & Intron 7 & 2695 & $\mathrm{C} / \mathrm{T}$ & \\
\hline 46 & Intron 4 & 21596 & $\mathrm{C} / \mathrm{T}$ & & 96 & Intron 7 & 3039 & $\mathrm{~A} / \mathrm{T}$ & rs1918249 \\
\hline 47 & Intron 4 & 22672 & $\mathrm{C} / \mathrm{T}$ & & 97 & Exon 8 & 56 & G/A(Ala175Thr) & rs1918248 \\
\hline 48 & Intron 4 & 22713 & $\mathrm{~A} / \mathrm{T}$ & & 98 & Intron 8 & 140 & $\mathrm{C} / \mathrm{T}$ & \\
\hline 49 & Intron 4 & 23010 & G/A & & 99 & $3^{\prime}$ Flanking & 179 & $\mathrm{C} / \mathrm{T}$ & \\
\hline 50 & Intron 4 & 23588 & $\mathrm{C} / \mathrm{T}$ & & 100 & 3' Flanking & 394 & $\mathrm{~A} / \mathrm{G}$ & rs1020696 \\
\hline
\end{tabular}

PEMT, phosphatidylethanolamine $N$-methyltransferase

Table 1F. Summary of SNPs detected in the PNMT gene

\begin{tabular}{llrll}
\hline No. & Location & Position $^{\mathrm{a}}$ & SNP & NCBI SNP ID \\
\hline 1 & 5' Flanking & -367 & $\mathrm{G}^{\mathrm{d}}$ & \\
2 & 5' Flanking & -161 & $\mathrm{G}^{\mathrm{d}}$ & \\
3 & Intron 1 & 35 & $\mathrm{G} / \mathrm{T}$ & \\
4 & 3' Flanking & 438 & $\mathrm{G} / \mathrm{A}$ & $\mathrm{rs} 407303$ \\
\hline
\end{tabular}

PNMT, phenylethanolamine $N$-methyltransferase

${ }^{\mathrm{d}}$ SNPs previously reported by Wu et al. (1999)

\section{References}

Axelrod J, Weinshilboum R (1972) Catecholamines. N Engl J Med 287:237-242

Baetge EE, Behringer RR, Messing A, Brinster RL, Palmiter RD (1988) Transgenic mice express the human phenylethanolamine $N$ methyltransferase gene in adrenal medulla and retina. Proc Natl Acad Sci U S A 85:3648-3652

Bertocci B, Miggiano V, Da Prada M, Dembic Z, Lahm H-W, Malherbe P (1991) Human catechol- $O$-methyltransferase: cloning and expression of the membrane-associated form. Proc Natl Acad Sci U S A 88:1416-1420 
Betito K, Mitchell JB, Bhatnagar S, Borksa P, Meaney MJ (1994) Regulation of the adrenomedullary catechcholaminergic system after mild, acute stress. Am J Physiol 267:R212-R220

Carducci C, Leuzzi V, Carducci C, Prudente S, Mercuri L, Antonozzi I (2000) Two new severe mutations causing guanidinoacetate methyltransferase deficiency. Mol Genet Metab 71:633-638

Cui Z, Vance JE, Chen MH, Voelker DR, Vance DE (1993) Cloning and expression of a novel phosphatidylethanolamine $\mathrm{N}$ methyltransferase. A specific biochemical and cytological marker for a unique membrane fraction in rat liver. J Biol Chem 268:1665516663

Cuomo R, Dattilo M, Pumpo R, Capuano G, Boselli L, Budillon G (1994) Nicotinamide methylation in patients with cirrhosis. J Hepatol 20:138-142

Eisenhofer G, Keiser H, Friberg P, Mezey E, Huynh T-T, Hiremagalur B, Ellingson T, Duddempudi S, Eijsbouts A, Lenders WM (1998) Plasma metanephrines are markers of pheochromocytoma produced by catechol- $O$-methyltransferase with tumors. J Clin Endocrinol Metab 83:2175-2185

Girardi NL, Shaywitz SE, Shaywitz BA, Marchione K, Fleischman SJ, Jones TW, Tamborlane WV (1995) Blunted catecholamine responses after glucose ingestion in children with attention deficit disorder. Pediatr Res 38:539-542

Goodman JE, Lavigne JA, Hengstler JG, Tanner B, Helzlsouer KJ, Yager JD (2000) Catechol-O-methyltransferase polymorphism is not associated with ovarian cancer risk. Cancer Epidemiol Biomarkers Prev 9:1373-1376

Hanna GL, Ornitz EM, Hariharan M (1996) Urinary epinephrine excretion during intelligence testing in attention-deficit hyperactivity disorder and normal boys. Biol Psychiatry 40:553-555

Huang C-S, Chern H-D, Chang K-J, Cheng C-W, Hsu S-M, Shen C-Y (1999) Breast cancer risk associated with genotype polymorphism of the estrogen-metabolizing genes $C Y P 17, C Y P 1 A 1$, and $C O M T$ : a multigenic study on cancer susceptibility. Cancer Res 59:4870-4875

Ilas J, Muhl A, Stöckler-Ipsiroglu S (2000) Guanidinoacetate methyltransferase (GAMT) deficiency: non-invasive enzymatic diagnosis of a newly recognized inborn error of metabolism. Clin Chim Acta 290:179-188

Klinteberg BA, Magnusson D (1989) Aggressiveness and hyperactive behavior as related to adrenaline excretion. Special Issue: personality and aggression. Eur J Personality 3:81-93

Kopin IJ (1985) Catecholamine metabolism: basic aspects and clinical significance. Pharmacol Rev 37:333-364

Lachman HM, Papolos DF, Saito T, Yu Y-M, Szumlanski CL, Weinshilboum RM (1996) Human catechol- $O$-methyltransferase pharmacogenetics: description of a functional polymorphism and its potential application to neuropsychiatric disorders. Pharmacogenetics 6:243-250

Lautala P, Ulmanen I, Taskinen J (2001) Molecular mechanisms controlling the rate and specificity of catechol $O$-methylation by human soluble catechol $O$-methyltransferase. Mol Pharmacol 59:393-402

Lavigne JA, Helzlsouer KJ, Huang H-Y, Strickland PT, Bell DA, Selmin O, Watson MA, Hoffman S, Comstock GW, Yager JD (1997) An association between the allele coding for a low activity variant of catechol- $O$-methyltransferase and the risk for breast cancer. Cancer Res 57:5493-5497

Loiselle J, Wollin W (1993) Mucosal histamine elimination and its effect on acid secretion in rabbit gastric mucosa. Gastroenterology 104:1013-1020

Lotta T, Vidgren J, Tilgmann C, Umanen I, Melen K, Julkunen I, Taskinen J (1995) Kinetics of human soluble and membrane bound catechol- $O$-methyltransferase: a revised mechanism and description of the thermolabile variant of the enzyme. Biochemistry 34:42024210

Lundström K, Salminen M, Jalanko A, Savolainen R, Ulmanen I (1991) Cloning and characterization of human placental catechol- $O$ methyltransferase cDNA. DNA Cell Biol 10:181-189

Millikan RC, Pittman GS, Tse C-KJ, Duell E, Newman B, Savitz D, Moorman PG, Boissy RJ, Bell DA (1998) Catechol- $O$ methyltransferase and breast cancer risk. Carcinogenesis 19:19431947

Ohnishi Y, Tanaka T, Yamada R, Suematsu K, Minami M, Fujii K, Hoki N, Kodama K, Nagata S, Hayashi T, Kinoshita N, Sato H, Sato Hid, Kuzuya T, Takeda H, Hori M, Nakamura Y (2000) Identification of 187 single nucleotide polymorphisms (SNPs) among 41 candi- date genes for ischemic heart disease in the Japanese population. Hum Genet 106:288-292

Pliszka SR, Maas JW, Rogeness GA, Baker J (1994) Urinary catecholamines in attention-deficit hyperactivity disorder with and without comorbid anxiety. J Am Acad Child Adolesc Psychiatry 33:1165-1173

Preuss CV, Wood TC, Szumlanski CL, Raftogianis RB, Otterness DM, Girard B, Scott MC, Weinshilboum RM (1998) Human histamine N-methyltransferase pharmacogenetics: common genetic polymorphisms that alter activity. Mol Pharmacol 53:708-717

Price RA, Scott MC, Weinshilboum RM (1993) Genetic segregation analysis of red blood cell (RBC) histamine N-methyltransferase (HNMT) activity. Genet Epidemiol 10:123-131

Rini J, Szumlanski C, Guerciolini R, Weinshilboum RM (1989) Human liver nicotinamide $\mathrm{N}$-methyltransferase: ion-pairing radiochemical assay, biochemical properties and individual variation. Clin Chim Acta 186:359-374

Salminen M, Lundström K, Tilgmann C, Savolainen R, Kalkkinen N, Ulmanen I (1990) Molecular cloning and characterization of rat liver catechol- $O$-methyltransferase. Gene 93:241-247

Schwartz JC, Arrang MM, Garbarg M, Pollaed H, Ruat M (1991) Histaminergic transmission in the mammalian brain. Physiol Rev 71:1-51

Scott MC, Van Loon JA, Weinshilboum RM (1988) Pharmacogenetics of $N$-methylation: heritability of human erythrocyte histamine $\mathrm{N}$ methyltransferase activity. Clin Pharm Ther 43:256-262

Seki T, Tanaka T, Nakamura Y (2000) Genomic structure and multiple single-nucleotide polymorphisms (SNPs) of the thiopurine Smethyltransferase (TPMT) gene. J Hum Genet 45:299-302

Smith M-L, Burnett D, Bennett P, Waring RH, Brown HM, Williams AC, Ramsden DB (1998) A direct correlation between nicotinamide $\mathrm{N}$-methyltransferase activity and protein levels in human liver cytosol. Biochim Biophys Acta 1422:238-244

Stöckler S, Holzbach U, Hanefeld F, Marquardt I, Helms G, Requart M, Hänicke W, Frahm J (1994) Creatine deficiency in the brain: a new, treatable inborn error of metabolism. Pediatr Res 36:409-413

Stöckler S, Hanefeld F, Frahm J (1996a) Creatine replacement therapy in guanidinoacetate methyltransferase deficiency, a novel inborn error of metabolism. Lancet 348:789-790

Stöckler S, Isbrandt D, Hanefeld F, Schmidt B, von Figura K (1996b) Guanidinoacetate methyltransferase deficiency: the first inborn error of creatine metabolism in man. Am J Hum Genet 58:914922

Stöckler S, Marescau B, De Deyn PP, Trijbels JM, Hanefeld F (1997) Guanidino compounds in guanidinoacetate methyltransferase deficiency, a new inborn error of creatine synthesis. Metabolism 46:1189-1193

Tenhunen J, Salminen M, Lundström K, Kiviluoto T, Savolainen R, Ulmanen I (1994) Genomic organization of the human catechol $O$ methyltransferase gene and its expression from two distinct promoters. Eur J Biochem 223:1049-1059

Thompson PA, Shields PG, Freudenheim JL, Stone A, Vena JE, Marshall JR, Graham S, Laughlin R, Nemoto T, Kadlubar FF, Ambrosone CB (1998) Genetic polymorphisms in catechol- $O$ methyltransferase, menopausal status, and breast cancer risk. Cancer Res 58:2107-2110

Ulmanen I, Peränen J, Tenhunen J, Tilgmann C, Karhunen T, Panula P, Bernasconi L, Aubry J-P, Lundström K (1997) Expression and intracellular localization of catechol O-methyltransferase in transfected mammalian cells. Eur J Biochem 243:452-459

Vance DE, Ridgway ND (1988) The methylation of phosphatidylethanolamine. Prog Lipid Res 27:61-79

Vance DE, Walkey CJ, Cui Z (1997) Phosphatidylethanolamine $N$ methyltransferase from liver. Biochim Biophys Acta 1348:142-150

Walker JB (1979) Creatine: biosynthesis, regulation, and function. Adv Enzymol Relat Areas Mol Biol 50:177-242

Walkey CJ, Donohue LR, Bronson R, Agellon LB, Vance DE (1997) Disruption of the murine gene encoding phosphatidylethanolamine $N$-methyltransferase. Proc Natl Acad Sci U S A 94:12880-12885

Walkey CJ, Shields DJ, Vance DE (1999) Identification of three novel cDNAs for human phosphatidylethanolamine $N$-methyltransferase and localization of the human gene on chromosome 17p11.2. Biochim Biophys Acta 1436:405-412

Wallimann T, Hemmer W (1994) Creatine kinase in non-muscle tissues and cells. Mol Cell Biochem 133/134:193-220 
Wasserman SI (1983) Mediators of immediate hypersensitivity. J Allergy Clin Immunol 72:101-115

Weinshilboum R (1989) Methyltransferase pharmacogenetics. Pharmacol Ther 43:77-90

Williams AC, Pall HS, Steventon GB, Green S, Buttrum S, Molloy H, Waring RH (1993) N-methylation of pyridines and Parkinson's disease. Adv Neurol 60:194-196

Wu S, Comings DE (1999) Two single nucleotide polymorphisms in the promoter region of the human phenylethanolamine $N$ methyltransferase PNMT gene. Psychiatr Genet 9:187-188

Yamada R, Tanaka T, Ohnishi Y, Suematsu K, Minami M, Seki T, Yukiok M, Maeda A, Murata N, Saiki O, Teshima R, Kudo O, Ishikawa K, Ueyosi A, Tateishi H, Inaba M, Goto H, Nishizawa $\mathrm{Y}$, Tohma S, Ochi T, Yamamoto K, Nakamura Y (2000) Identification of 142 single nucleotide polymorphisms in 41 candidate genes for rheumatoid arthritis in the Japanese population. Hum Genet 106:293-297

Yan L, Otterness DM, Weinshilboum RM (1999) Human nicotinamide $N$-methyltransferase pharmacogenetics: gene sequence analysis and promoter characterization. Pharmacogenetics 9:307-316

Yan L, Galinsky RE, Bernstein JA, Liggett SB, Weinshilboum RM (2000a) Histamine N-methyltransferase pharmacogenetics: association of a common functional polymorphism with asthma. Pharmacogenetics 10:261-266

Yan L, Szumlanski CL, Rice SR, Sobell JL, Lachman HM, Weinshilboum RM (2000b) Histamine N-methyltransferase functional polymorphism: lack of association with schizophrenia. Am J Med Genet (Neuropsychiatr Genet) 96:404-406

Zhu BT, Conney AH (1998) Functional role of estrogen metabolism in target cells: review and perspectives. Carcinogenesis 19:1-27 